\title{
Z adresownika poetki. Śladami listów Kazimiery Iłłakowiczówny w bibliotekach polskich
}

Streszczenie. Niniejszy artykuł porusza pomijane dotychczas w literaturze zagadnienie korespondencji wybitnej poetki i tłumaczki Kazimiery Iłłakowiczówny. Analiza charakteru spuścizny znajdującej się w czterech dużych bibliotekach: Bibliotece Kórnickiej PAN, Bibliotece Raczyńskich w Poznaniu, Wojewódzkiej i Miejskiej Bibliotece Publicznej w Bydgoszczy oraz Bibliotece Uniwersyteckiej w Poznaniu pozwala spojrzeć szerzej na problem niekompletnej i szczątkowej biografii poetki, równocześnie skupia tę rozproszoną dziś spuściznę.

Bogata i różnorodna twórczość Kazimiery Iłłakowiczówny doczekała się wydania zbiorowego poezji (Toruń 1998) pod redakcją Jacka Biesiady i Aleksandry Żurawskiej--Włoszczyńskiej, inaczej jest z jej biografią. Zapomniany w historii literatury „słowik wileński" kryje się w swoich listach w archiwach zbiorów bibliotecznych. Bez Kazimiery Iłłakowiczówny barwna epoka międzywojenna wydaje się niekompletna. Traci mistrzynię osobliwej dyskrecji, metaforyzacji rzeczywistości oraz lekkiej ironii.

SŁowA KLuczowe: Kazimiera Iłłakowiczówna, spuścizna epistolograficzna, korespondencja literacka, Poznań XX wiek.

Stopniowo traciła wzrok. Pamiętam, że trzeba było układać jej rękę i pilnować, aby nie pisała poza kartką. Używała bardzo grubych pisaków. To było takie pisanie po omacku ${ }^{1}$.

Tak zapamiętała Kazimierę Iłłakowiczównę jej opiekunka Elżbieta Wesołowska, obecnie profesor w Instytucie Filologii Klasycznej Uniwersyte-

${ }^{1}$ E. Wesołowska, Wizyty u Starszej Pani. Garść wspomnień i kilka cytatów, w: Kiedy przebije się źródto, napiją się wszyscy. W25. rocznice odejścia Kazimiery Iłłakowiczówny, red. J.K. Pytel, Poznań 2008, s. 227. 
tu im. Adama Mickiewicza w Poznaniu. Razem z dwiema siostrami „była na służbie", jak sama pisze, u Starszej Pani. Kazimiera Iłłakowiczówna nazywała je Przemkównami, gdyż były córkami samego Przemysława Bystrzyckiego. Lata 70. to właśnie ten okres, w którym panny Przemkówny towarzyszyły poetce $\mathrm{w}$ wypełnianiu domowych obowiązków. Ponadto czytały poetce prasę codzienną i pomagały przy odpisywaniu na obszerną korespondencję, a później - wraz postępem choroby - pisały listy pod dyktando poetki. Elżbieta Wesołowska podkreśla, że był to czas poświęcony tylko autorce Szeptem, trudny i wyczerpujący. Starsza Pani wyznaczała twarde zasady - albo trzeba się było im podporządkować, albo odejść.

Każdy dzień poetki składał się z czynności dokładnie zaplanowanych, ujętych w nieprzekraczalne granice. W muzeum-pracowni znajduje się do dziś ułożony przez nią harmonogram korzystania ze wspólnej łazienki. Z kolei Łucja Danielewska opisuje, jak to często nobilitowani goście byli odprawiani z niczym, gdyż spóźnili się kilka minut na umówioną rozmowę z poetką. $W$ ten rygorystyczny plan dnia wpisywał się również czas na korespondencję.

Korespondencja zawsze stanowiła ważny element życia Kazimiery Iłłakowiczówny. W latach międzywojennych, gdy pracowała jako urzędniczka w Ministerstwie Spraw Zagranicznych, a potem jako sekretarz marszałka Piłsudskiego, musiała zmagać się z zalewem listów. Wykształciło to w niej nawyk niezwłocznego odpisywania na otrzymaną korespondencję. Będąc na emigracji w Rumunii i na Węgrzech, tylko listownie mogła porozumiewać się z rodziną i znajomymi w Polsce. Po powrocie do Polski w 1947 roku poetka wciąż słała setki kartek pocztowych i listów. Mimo że osiedliła się w Poznaniu i założyła w mieszkaniu telefon, nigdy nie zrezygnowała $\mathrm{z}$ tradycyjnej formy komunikacji.

Można się zastanawiać, dlaczego tak zawzięcie utrzymywała dość czasochłonny kontakt listowny. Dlaczego nawet po utracie wzroku nie pozwoliła sobie na zaniechanie korespondencji. Odpowiedzi można szukać w tak silnie podkreślanej przez poetkę niezależności, którą chciała mieć w każdej dziedzinie życia. Korespondencja nie wymaga kontaktu fizycznego z odbiorca, czyli nie narusza przestrzeni osobistej. Ponadto umożliwia spotkanie, nawet mimo dużej odległości. Warto wspomnieć, że Kazimiera Iłłakowiczówna miała znajomych rozrzuconych po całej Polsce i poza jej granicami. W jej adresowniku ${ }^{2}$, który wszedł do zbiorów Biblioteki Kórnickiej PAN, znajdują się takie nazwi-

\footnotetext{
${ }^{2}$ Biblioteka Kórnicka PAN, Archiwum Kazimiery Iłłakowiczówny, sygn. BK 12118, k. 204-298.
} 
ska, jak: Julian Tuwim, Jarosław Iwaszkiewicz, Wojciech Bąk, Roman Brandstaetter oraz Maria Dąbrowska.

Prócz korespondencji z osobami prywatnymi poetka listownie angażowała się w życie społeczne i polityczne powojennej Polski. Wystarczy wspomnieć o apelu do polskiej inteligencji w obronie Wojciecha Bąka. Kiedy środowisko literackie milczało, Iłłakowiczówna wołała głośno w swym liście z 1956 roku:

wydaje się rzeczą niesłychana, by grono kolegów, zamiast bronić pisarza, przyczyniało się do zaszczuwania go. Rolą Związku winna być pomoc, zabezpieczenia praw ludzkich pisarza, troska o jego byt [...], stawanie pomiędzy nim a surową codziennością, z którą wrażliwy artysta więcej się łamie niż kto inny ${ }^{3}$.

Szeroka korespondencja autorki Niewczesnych wynurzeń znalazła się w zbiorach czterech bibliotek polskich, choć z pewnością wiele z niej jest wciąż w rękach prywatnych. Największą część spuścizny poetki otrzymała Biblioteka Kórnicka PAN. Przekazywanie materiałów odbywało się w kilku etapach. Oto przykładowy list ówczesnego dyrektora Biblioteki do Kazimiery Iłłakowiczówny:

Wielce Szanowna Pani,

W imieniu Dyrekcji Biblioteki Kórnickiej PAN z uprzejmym podziękowaniem potwierdzam odbiór cennego depozytu materiałów związanych z prelekcjami Szanownej Pani w różnych krajach Europy. Ogólny spis materiałów zdeponowanych przedkładamy w załączeniu do akceptacji - szczegółową ich listę możemy wykonać $\mathrm{w}$ terminie późniejszym, bowiem łączy się to z uporządkowaniem całości w obrębie poszczególnych teczek. [...] Depozyt, zgodnie z Pani żądaniem, zostanie zalakowany i złożony w dziale rękopisów, a udostępniony jedynie za Jej zgodą. Na wypadek śmierci przechodzi na własność Biblioteki Kórnickiej PAN ${ }^{4}$.

Niestety, z listu nie wynika, jaki rodzaj depozytu złożyła poetka: czy był to depozyt czasowy, czy wieczysty. Można domniemywać, że był to ten drugi rodzaj depozytu, gdyż nigdzie nie podaje się daty wygaśnięcia umowy depozytowej. Wszelkie prawa co do własności wygasają w dniu śmierci.

${ }^{3}$ Cyt. za: R. Jędrzejewska-Wróbel, Potykając się o ciemność. Powojenna korespondencja Kazimiery Iłłakowiczówny, w: Z cienia niepamięci do światła: Wojciech Bąk, Kazimiera Iłłakowiczówna, Roman Brandstaetter, red. E. Krawiecka, Poznań 2006, s. 84.

${ }^{4}$ Biblioteka Kórnicka PAN, Dary z 1966-1974 roku, k. 196. 
Część spuścizny poetka przekazała Bibliotece w postaci depozytu, część została zakupiona do zbiorów. Prócz rękopisów utworów poetyckich i prozatorskich, dokumentów osobistych, jak bilet okresowy na komunikację miejską zbiory kórnickie zawierają największą kolekcję listów poetki. Stanowią one ponad połowę archiwum. Zostały pogrupowane alfabetycznie.

Mimo że zbiory Biblioteki są bardzo obszerne i stanowią bezcenne źródło do badań biograficznych, to jednak ich charakter określiłabym jako oficjalny. Znajduje się tam tylko nieliczna korespondencja prywatna poetki. Większą część kolekcji stanową listy do wydawców, instytucji, osób z życia kulturalnego. Ciekawym wyjątkiem jest bezcenny list Julii Zan, córki Klemensa Zana, do Kazimiery Iłłakowiczówny. Julia opisuje w nim szczegóły zagadkowej śmierci ojca:

Katastrofa nastąiłia w powrotnej drodze z Grodna. Ojciec jechał sam w przedziale I klasy. Jak następnie ustalono - spał. Gdy pociąg wjechał w tunel (na drodze do Wilna), pasażerowie sąsiedniego wagonu usłyszeli szereg wystrzałów. Kilka kul utkwiło w oparciu kanapy.

Według opinii badających tę smutną sprawę było to bezwzględnie morderstwo. Zabójca został nasłany przez Generała-Gubernatora Klinkenberga.

W kilka tygodni po śmierci naszego Ojca zgłosił się robotnik kolejowy z oświadczeniem, że jest gotów wskazać zabójcę i być świadkiem w sądzie w razie wytoczenia sprawy. Nie zgłosił się jednak powtórnie. Bał się widać - po zastanowieniu - konsekwencji ${ }^{5}$.

List ten pozwala rozszyfrować dwie sprawy: zabójstwa Klemensa Zana oraz kontaktów autorki Portretów imion z rodzeństwem Zanów. Korespondencja z Julia, prawowitą wnuczką Tomasza Zana, potwierdza fakt, iż Iłłakowiczówna przyznała się do pokrewieństwa z rodziną Zanów (w dalszych słowach listu Julia wspomina o „naszym ojcu”).

Wśród korespondencji z wydawcami znajdziemy interesujący plik listów do Ryszarda Matuszewskiego, ówczesnego kierownika działu literatury Spółdzielni Wydawniczej "Czytelnik”. Nakładem "Czytelnika” ukazał się w 1966 roku ostatni autorski tomik poezji Kazimiery Iłłakowiczówny Szeptem. Korespondencja ta stanowi w dużej mierze dokumentację działalności cenzury na rynku wydawniczym. Matuszewski wprawdzie zachwyca się maszynopisem Szeptem, lecz już w drugim liście do poetki donosi:

${ }^{5}$ Biblioteka Kórnicka PAN, Archiwum Kazimiery Iłakowiczówny, sygn. BK 12113, k. 146-147. 
aby była Pani łaskawa zrezygnować z dwu wierszy, których drukować nie możemy: „Rozstrzelano moje serce” i „Straconym buntownikom”. Myślę, że motywacji przedstawiać Pani nie muszę w liście, najchętniej to uczynię w razie potrzeby przy osobistym kontakcie. Prosimy o wyrażenie zgody ${ }^{6}$.

Te dwa wiersze były zbyt kłopotliwe dla władzy. Pierwszy z nich w Wielkopolsce ukazał się dopiero w roku 1981 w "Głosie Wielkopolskim" (nr 119). Drugi, niestety, nie tylko został usunięty z egzemplarzy maszynopisów znajdujących się w Bibliotece Kórnickiej, ale również nigdy nie wyszedł drukiem ani w żadnej gazecie, ani w zbiorze poezji. Jego treść pozostaje jak dotąd nieznana.

Korespondencja poetki znalazła się również w zbiorach trzech innych bibliotek. Są to już o wiele mniejsze spuścizny, co nie oznacza iż mniej interesujące dla badaczy. Przyjrzyjmy się najpierw dokumentom znajdującym się w posiadaniu Biblioteki Raczyńskich w Poznaniu. Należy zaznaczyć, że Biblioteka ta stanowiła ważny element poznańskiej biografii poetki. To w jej filiach odbywały się regularnie spotkania z czytelnikami i młodymi pisarzami. W 1984 roku utworzono w dawnym mieszkaniu poetki przy ulicy Gajowej muzeum-pracownię, gdzie do dziś można oglądać księgozbiór prywatny Iłłakowiczówny. Oto fragment protokołu z utworzenia pracowni:

W dniu 9 IV 1984 r. zostały przekazane przez ob. Janinę Czerwijowską [...] przedmioty stanowiące wyposażenie mieszkania poetki oraz przedmioty jej użytku osobistego. [...] Miejska Biblioteka Publiczna im. E. Raczyńskiego reprezentowana przez ob. dyrektora Janusza Dembskiego w/w przedmioty przyjmuje $\mathrm{w}$ formie darowizny ${ }^{7}$.

Prócz eksponatów muzealnych Biblioteka może się poszczycić niezwykle cennym zbiorem listów Kazimiery Iłłakowiczówny do siostry, Barbary Czerwijowskiej, oraz korespondencją z siostrzenica, Janiną Czerwijowską. Spuścizna ta znajduje się obecnie w Ośrodku Dokumentacji Wielkopolskiego Środowiska Literackiego Biblioteki Raczyńskich. Obejmuje trzy teki z luźnymi listami, pisanymi w większości na kartkach pocztowych (sygn. DL 208-DL 210).

Archiwum literackie w zbiorach Biblioteki Raczyńskich można określić jako najbardziej osobiste, gdyż w jego skład wchodzi głównie korespondencja z najbliższymi. Listy zawierają informacje, które nigdy nie miały

\footnotetext{
${ }^{6}$ Biblioteka Kórnicka PAN, Archiwum Kazimiery Iłłakowiczówny, Mf 8401, k. 81.

${ }^{7}$ Biblioteka Raczyńskich w Poznaniu, Protokót zdawczo-odbiorczy przedmiotów znajdujacych się w mieszkaniu-pracowni Kazimiery Iłłakowiczówny.
} 
zostać ujawnione, ponieważ ich odbiorcą była rodzina poetki. Dlatego są nadzwyczaj szczere i bezpośrednie. Mimowolnie odsłaniają liczne tajemnice rodziny Iłłakowiczów. Poetka po śmierci siostry Barbary Czerwijowskiej usilnie zabiegała o przekazanie jej całej korespondencji. Do dziś pozostaje zagadka, co zamierzała zrobić z tymi listami. Czy chciała je zniszczyć? Czy zostawiła taką dyspozycję swojej siostrzenicy? Na szczęście, na przekór usiłowaniom Iłły (jak poetkę nazywali przyjaciele), listy te przetrwały i stanowią jedyny w swoim rodzaju zapis „rozmów” sióstr.

Jakie tematy podejmowały siostry w listach? Można pokusić się o stwierdzenie, iż pisały do siebie niemal o wszystkim. Znajdują się tam opisy czynności codziennych, spotkań, zmartwień i chwil radości. Trzeba zaznaczyć, że wymiana listowna między siostrami była bardzo ożywiona:

Droga Basiu, nie rozumiem tego Twego ciagłego prawowania się o listy. Miewam dzień, że nieraz do 20 listów Tobie odpisuję właściwie co 2-3 dni. [...] Obecnie odpisuję na kartkę z 2 b. m. Za dwa dni doniesiesz mi znowu, że długo nie pisałam. Zajmuj się czymś, czytaj coś, a listy wkładaj do pudełka w miarę jak przychodzą, to będziesz miała najświeższą datę na wierzchu. Życie moje jest zapełnione od świtu do nocy pisaniem. Załóżcie sobie wreszcie telefon, to będziesz mogła tutaj zadzwonić 8 .

Intensywny styl życia „wileńskiego słowika” kontrastował ze spokojnym, introwertycznym światem Barbary Czerwijowskiej. Gdyby przyjrzeć się wszystkim listom Iłły do siostry, każdy z nich ma niezmienną konstrukcję: rozpoczyna się zwrotem do odbiorcy - „Moja Najdroższa Basieńko”, ,"Moja droga, Kochana Basieńko”, ,Kochana Basiu” - a kończy się słowami: „,Ściskam, Ściskam najserdeczniej”. Ponadto każdy list składa się z trzech zasadniczych części: odniesienie się do ostatniego listu, relacja z wydarzeń obecnych, informacja o stanie pogody. Sporadycznie pojawiają się wiadomości o kolejnych wydaniach tomików poetyckich. W jednym z listów czytamy:

Zupełnie zapomniałam Ciebie uprzedzić, że pozwoliłam sobie $\mathrm{w}$ umowie o wydanie „Imion” wymienić Ciebie jako osobę, która może zrobić korektę w moim zastępstwie. Jest zupełnie mało prawdopodobne, żeby taka możliwość zaistniała $[\ldots]^{9}$.

${ }^{8}$ Biblioteka Raczyńskich. Ośrodek Dokumentacji Wielkopolskiego Środowiska Literackiego, Listy Kazimiery Iłłakowiczówny do Barbary Czerwijowskiej, t. 3, k. 122, sygn. DL/210.

${ }^{9}$ Ibidem, t. 3, k. 173, sygn. DL/210. 
Niestety nie wiadomo, czy Barbara Zan-Czerwijowska (takim pseudonimem literackim się posługiwała) otrzymywała od siostry pierwsze wydania tomików poezji. Pewne jest, iż właśnie za pośrednictwem poczty obie panie słały paczki zawierające domowe smakołyki. Mogły to być ciasta własnego wypieku, owoce czy inne przetwory:

Posłałam Ci wczoraj trochę ciasta własnego wypieku. Uprzedzam, że jest tłuste i z jajami, a przy tem mało słodkie. Radzę Ci polukrować je grubo to będzie dobre $\mathrm{w}$ smaku ${ }^{10}$.

W innym liście Kazimiera udzielała rad starszej siostrze:

Dziękuję [...] za sucharki, które pojadam z wielką „,aprecjacją”. Myślę, że jest w nich zbyt wiele masła - wystarczyłoby mleko i jaja. O ile sobie przypominam, to kryształ zmieszany z cynamonem był jakby trochę - częściowo - rozpuszczony i dlatego lepiej się trzymał niż Twój, lepił się do swej bazy ${ }^{11}$.

Życie w powojennej Polsce zmusiło poetkę do nauczenia się wielu domowych obowiązków, których niegdyś unikała. W liście do siostry z dumą oświadczała, że opanowała sztukę przyrządzania ryb:

Nauczyłam się czyścić i skrobać ryby. Masło można zawsze dostać „na lewo” bez kolejki ale ja wolę ryby na margarynie. Nigdy bym nie stała w żadnej kolejce - chyba dla kogoś. Tak łatwo się obejść! Po co to mięso... ${ }^{12}$.

Korespondencja między siostrami traktowała też o tematach trudnych, o ciężkich doświadczeniach życiowych. Najpierw samobójcza śmierć starszej córki Barbary, Krystyny Czerwijowskiej, następnie odejście samej Barbary, pięknie opisane przez Janinę Czerwijowską:

Mama do nas jednak nie wróciła z tego półsnu zawieszonego między życiem a śmiercią. Dzisiaj rano przekroczyła tę drugą granicę - wieczność. Zasnęła tak spokojnie i cicho [...]. Nie było mnie przy tym, ale podobno śmierć miała bardzo lekką, nie odzyskawszy przytomności ${ }^{13}$.

\footnotetext{
${ }^{10}$ Ibidem, t. 1, k. 86, sygn. DL/208.

${ }^{11}$ Ibidem, t. 3, k. 178, sygn. DL/210.

12 Ibidem, t. 1, k. 62, sygn. DL/208.

${ }^{13}$ Biblioteka Raczyńskich w Poznaniu, Listy Janiny Czerwijowskiej do Kazimiery Iłłakowiczówny (12.04.1974).
} 
Zbiory Biblioteki Raczyńskich uzupełniają w wielu miejscach biografię poetki, pozwalają poznać ją od strony prywatnej, tak skrzętnie ukrywanej.

W Wojewódzkiej i Miejskiej Bibliotece Publicznej w Bydgoszczy znajdziemy z kolei korespondencje poetki o bardzo podobnym charakterze do zbiorów Biblioteki Raczyńskich. Większość znajdujących się tam materiałów Kazimiera Iłłakowiczówna przekazała w latach 50. w postaci darów (pierwsza data w inwentarzu to 1958 rok), część jest darem Marii Krupnikowej.

Do najciekawszego zbioru należy korespondencja z dwiema paniami: Jadwigą Łozicką i Julią Pugetową z Kwileckich. Obie spuścizny różnią się znacznie stopniem zażyłości z adresatkami. Julia Pugetowa była dobrą znajomą poetki. Najstarszy list opatrzony jest datą 1940, czyli pisany był w okresie, w którym Iłłakowiczówna przebywała na emigracji:

Jestem tutaj od września i uczę języków, z czego się utrzymuję. Na Lipowej schroniły się Krysia i Janka Czerwijowskie, moje siostrzenice i pozostaje tam Grabosia. [...] Moja siostra wyewakuowana tutaj, jest daleko w innej części kraju ${ }^{14}$.

Wzruszający jest list, w którym Kazimiera Iłłakowiczówna wyjawia nieznaną dotąd przyczynę pewnego oddalenia emocjonalnego od siostry i siostrzenic po powrocie do Polski:

Najbliższa mi w Polsce osoba - stara Grabosia, jest niestety niepiśmienna i w ogóle też w pewien sposób poza życiem, bo w Przytułku na [...] (pokój 11, pawilon 1, Schronisko Maryji Panny, [...] 4, Warszawa). Warowała wiernie w moim mieszkaniu, które ocalało, ale dom mojej siostry się spalił i musiałam oddać i mieszkanie i rzeczy jej i jej córkom w posiadanie. Podarowałam im wszystko, oprócz małego spisu rzeczy (trochę ubrań i umeblowanie pierwszego pokoju), one zaś nie zżyły się z Grabosią i wyprawiły ją do Schroniska. Bardzo to jest dla mnie bolesne i cały ten proces ogromnie mnie tutaj przygnębiał, a wreszcie oddalił zupełnie od siostry, której zresztą tak jak i dziewczynek wcale nie chcę sądzić, ale nie mogę o nich bez przykrości myśleć ${ }^{15}$.

Spuścizna bydgoska zawiera też list do Grabosi, czyli Józefy Grabowskiej, z 24 lipca 1948 roku. Poetka pisała z Hotelu Continental w Poznaniu:

\footnotetext{
${ }^{14}$ Wojewódzka i Miejska Biblioteka Publiczna w Bydgoszczy, Korespondencja Kazimiery Itłakowiczówny z lat 1939-1951 (12.05.1940), rkp. 840/II.

${ }^{15}$ Ibidem (9.03.1958), rkp. 881 II.
} 
Pamięta Grabosia jak wtedy Grabosia dostała egzemy na rękach od sprzątania? Ogromnie sobie wyrzucam, ze wtedy nie wzięłam paru froterów, żeby zcyklinowali podłogi, tylko dałam się Grabosi tyle męczyć. Ale wtedy zdawało mi się, że Grabosia i Łojek to dosyć, no i obie bardzo nie lubiłyśmy w domu obcych majstrów. [...] Obecnie jadę do Poznania, żeby tam szukać pokoju na stałe, a przynajmniej na tę zimę, bo dłużej nie mogę krępować swoją osobą mojej siostry i moich siostrzenic. Pojadę jednak jeszcze do Warszawy po rzeczy i wtedy na pewno się zobaczymy ${ }^{16}$.

Warto przyjrzeć się również korespondencji z Jadwigą Łozicką. Pierwszy list między paniami datowany jest na 3 lutego 1930 roku, ostatni na rok 1958. Elementem wyróżniającym tę korespondencję jest fakt, iż Iłłakowiczówna zupełnie nie może przypomnieć sobie znajomości z adresatką. Poetka tłumaczy to utratą pamięci spowodowaną ciężkimi przeżyciami wojennymi:

Na skutek ciężkiej pracy na froncie zupełnie straciłam pamięć, toteż wyznam szczerze, że nie przypominam sobie Pani. Czasy te są dla mnie zupełnie jak nieistniejące, tak zapomniane. Szczerze wdzięczna tem bardziej jestem za Pani życzliwą pamięć i uprzejmą ocenę moich wierszy.

Łączę najlepsze pozdrowienia ${ }^{17}$.

Mimo zapewnień Jadwigi Łozickiej, że panie poznały się w Petersburgu, poetka nie mogła sobie przypomnieć adresatki, co nie zraziło pani Jadwigi przed utrzymywaniem kontaktu korespondencyjnego. W zbiorach bydgoskich znajdziemy między innymi list datowany na 1939 rok:

Pani najłaskawsza,

tyle lat minęło - bo przecie ponad 50, skoro Pani wspomina mój pierwszy przyjazd do Petersburga - że nie tylko Pani, ale nawet p. Przyborowskich zupełnie sobie nie przypominam. Niestety, nie straciłam pamięci na skutek wieku, lecz nigdy jej nie miałam, stąd same luki... Czy to był dentysta? I czy pani była niewielką jasną blondynką? Nie pamiętam również ani Pani listów w 1939 ani mojej odpowiedzi. Cóż robić, muszę wierzyć i wierzę z przyjemnością tym, którzy są tak dobrzy, że mnie pamiętają - wierzę więc i Pani ${ }^{18}$.

W liście tym po raz pierwszy zostaje wspomniana Bydgoszcz oraz znajomość Kazimiery Iłłakowiczówny z Marią Krupnikową:

\footnotetext{
${ }^{16}$ Ibidem (24.07.1948).

${ }^{17}$ Ibidem (3.02.1930).

${ }^{18}$ Ibidem (9.03.1958).
} 
Niechże mi Pani napisze, co Pani w tej Bydgoszczy robi. Mam tam tylko jedną znajomą - i to raczej znajomość pobieżna - p. Krupnikową z Biblioteki Miejskiej. Miasto zdaje się dość kulturalne i o klimacie raczej zdrowym ${ }^{19}$.

Panie planowały spotkać się podczas pobytu poetki w Bydgoszczy. 3 maja 1958 roku poetka miała odczyt w bydgoskim Związku Literatów. Niestety, drogi obu pań się nie zeszły. Na tych dwóch kartkach pocztowych kończy się korespondencja zachowana w zbiorach Biblioteki.

Ostatnią biblioteka, w której zbiorach znajduje się pokaźny zbiór korespondencji Iłłakowiczówny, jest Biblioteka Uniwersytecka w Poznaniu. Obok brulionów z rękopisami poezji z lat 1939-1947 znajdziemy listy z lat 1956-1966 do Józefa Iwaszkiewicza, brata Jarosława, oraz plik listów do Jadwigi Hlebowicz z lat 1962-1974.

Korespondencja z Józefem Iwaszkiewiczem jest bardzo lakoniczna. Dotyczy w większości wymiany życzeń świątecznych: „Najuprzejmiej dziękuję za pamięć. Iłłakowiczówna" ${ }^{20}$ lub zawiera zaproszenia na spotkania autorskie: „W poniedziałek 9 maja o godz. 20 w klubie Odnowa, Wielka 1 odbędzie się wieczór autorski Kazimiery Iłłakowiczówny, wstęp wolny"21. Była to grzecznościowa wymiana kartek okolicznościowych.

Inaczej wygląda kontakt listowny między poetką a Jadwigą Hlebowicz. Już w pierwszym liście dowiadujemy się, iż była ona uczennicą autorki Fotoplastykonu:

Droga Pani, serdecznie dziękuję za wierną pamięć. Bardzo mi zawsze brak Pani wśród moich uczniów. Gloria in excelsis! ${ }^{22}$.

W kolejnym liście poetka dopytuje się, kiedy uczennica znów zacznie uczęszczać na lekcje:

Droga Pani, dziękuję za słówko i proszę o podanie mi w jakiś sposób znaku, kiedy Pani przychodzi na lekcje. Serdeczne ukłony, K. I. ${ }^{23}$

Mimo iż korespondencja ta jest znacznie obszerniejsza niż z Iwaszkiewiczem, to nadal można ją określić jako okolicznościową. Znajdziemy

${ }^{19}$ Ibidem.

${ }^{20}$ Biblioteka Uniwersytecka w Poznaniu, Listy Kazimiery Iłłakowiczówny do Józefa Iwaszkiewicza z lat 1956-1966, k. 13, rkp. 3720.

${ }^{21}$ Ibidem, k. 9.

${ }^{22}$ Biblioteka Uniwersytecka w Poznaniu, Korespondencja Kazimiery Iłłakowiczówny z Jadwiga Hlebowiczowa z lat 1962-1974, k. 27, rkp. 3718.

${ }^{23}$ Ibidem, k. 16. 
w niej przede wszystkim kartki z życzeniami świątecznymi. Korespondencja wydaje się podtrzymywana głównie ze strony Jadwigi Hlebowicz. Na święta Wielkiej Nocy 1973 roku poetka pisała: „Gorąco dziękuję za życzliwą pamięć. Przesyłam wyrazy najżyczliwszej pamięci oraz życzenia łask bożych" ${ }^{24}$. Kolejna kartka datowana jest dopiero na grudzień tego roku i znów zawiera podziękowania za życzenia świąteczne i pamięć.

Najistotniejsza w tej korespondencji wydaje się nie tyle sama treść listów, ile ich zapis graficzny. Kazimiera Iłłakowiczówna od lat 70. zaczęła powoli tracić wzrok. Źle leczona jaskra z każdym dniem pozbawiała poetkę możliwości samodzielnego pisania. Ratunkiem, lecz na krótko, stały się grube, czarne pisaki, którymi kreśliła nieporadne, dziwnie duże litery. Prosiła swoich korespondentów, by pisali również czarnym kolorem na białej kartce, bo to była jeszcze w stanie odczytać sama. Kiedy już zupełnie jej świat stracił wszelkie kolory i kształty, posługiwała się ręką i oczami opiekunek, by kontynuować korespondencję.

Zbiory Biblioteki Uniwersyteckiej zawierają milczące świadectwo walki poetki z chorobą. Pismo autorki Lekkomyślnego serca w każdym kolejnym liście jest mniej czytelne, bardziej koślawe, niepewne. Litery często nachodzą na siebie, są niedopracowane, chwiejne. W kartach z 1974 roku pojawił się obcy charakter pisma. Początkowo wpisywał tylko adres, treść listu była wciąż mozolnie i z wielkim trudem kreślona przez Kazimierę Iłłakowiczównę. Na przykładzie tych kartek pocztowych można obserwować zmagania tej niegdyś samodzielnej kobiety z otaczającą ją ciemnościa, można podziwiać usilne pragnienie pozostania w życiu znajomych i rodziny, można dostrzec obawę przed samotnością. Niezwykle przejmująco w tych okolicznościach brzmi wiersz Kazimiery Iłłakowiczówny pozostający wciąż w rękopisie:

Jeśli uda się przeżyć ciemność,

wtedy zaczną cuda

dziać się ze mną.

Jeśli nie potknie się

stopa w przejściu,

to $\mathrm{w}$ stokrotną

rzeczywistość wejdzie.

Jeśli w porę ujmie dłoń

czarodziejską laskę,

to wystrzeli wreszcie most

\footnotetext{
${ }^{24}$ Ibidem, k. 23.
} 
nad przepaścią.

i nad czasem - lekko kulejący -

człek przebiegnie

potrącając „wczoraj”, ,dziś” i ,jutro”,

„już” i „kiedyś”"25.

Każda z opisanych bibliotek posiada niepowtarzalną kolekcję spuścizny poetki. Jeśliby połączyć je ze soba, będą stanowiły niemal spójną całość. Do pełnego obrazu brakuje zbiorów znajdujących się nadal w rękach prywatnych. Idealną sytuacją dla badacza byłoby utworzenie jednej kolekcji archiwaliów Kazimiery Iłłakowiczówny, lecz obecnie jest to niemożliwe.

Niniejszy artykuł to jedynie preludium do analizy tej niesamowicie obfitej i rozległej tematycznie korespondencji, którą latami prowadziła Kazimiera Iłłakowiczówna.

\author{
Monika Chuda
}

\title{
From the addressbook and planner of a poetess. On the trail and through the letters written by Kazimiera Iłłakowiczówna currently held in Polish libraries.
}

\begin{abstract}
Aвstract. The present article discusses the correspondence of the distinguished poetess and translator, Kazimiera Iłłakowiczówna. In the literature of the subject these issues have not yet been addressed adequately and satisfactorily. An analysis of the nature of the written legacy of the poetess, currently housed in four large Polish libraries: Kórnik Library of the Polish Academy of Sciences, Raczyński Municipal Library in Poznań, Public Library in Bydgoszcz and Poznań University Library, allows us to have a broad outlook to issues related to the incomplete and fragmented biography of the poetess. At the same time, it makes it possible to integrate somehow this dispersed legacy.

The rich and varied literary output of Kazimiera Iłłakiewiczówna has been finally integrated with the edition of a collection of her poems (Toruń, 1998, ed. Jacek Biesiada and Aleksandra Żurawska-Wołoszyńska. Unfortunately, this is not the case with Iłłakiewiczówna's biography. The mysteries of the biographical past of the nearly forgotten "Wilno nightingale" still remain to be discovered in archives and library col-
\end{abstract}

${ }^{25}$ Biblioteka Kórnicka PAN, Archiwum Kazimiery Iłłakowiczówny, sygn. 12022 II, k. 33 . 
lections. Without Iłłakiewiczówna, the colourful epoch of the literary interwar period seems though to be incomplete. It clearly lacks the mistress of the singular discreetness, methaphorization of realities and her irony light as a breath.

KEY wORDs: Kazimiera Iłłakowiczówna, epistolographical legacy; literary correspondence, Poznań $-20^{\text {th }}$ century. 
